\title{
Pengukuran Kinerja Sustainability Menggunakan Metode Sustainability Performance Metrics \\ (Studi Kasus: Sistem Informasi Management Praktik Kerja Nyata Informatika UMM)
}

\author{
Gita Indah Marthasari ${ }^{*}$, Yufis Azhar ${ }^{2}$, Elza Norazizah ${ }^{3}$ \\ 1,2,3 Teknik Informatika/Universitas Muhammadiyah Malang \\ gita@umm.ac.id ${ }^{* 1}$, yufis@umm.ac.id ${ }^{2}$, elzaazizah175@gmail.com ${ }^{3}$
}

\begin{abstract}
Abstrak
Sistem Informasi Management Praktik Kerja Nyata (SIM PKN) adalah fasilitas pelayanan universitas muhammadiyah malang teknik informatika kepada mahasiswa, dosen akademik dan kalangan akademik lainnya dengan menyediakan Sistem Informasi akademik yang sesuai dengan perkembangan yang ada. Penggunaan SIM PKN memiliki kemungkinan untuk digunakan secara berkelanjutan. Tanpa adanya perubahan yang signifikan, sistem ini akan sulit untuk memenuhi kebutuhan yang sifatnya berkelanjutan. Oleh karena itu diperlukan pengukuran sustainability menggunakan sustainability performance metrics pada SIM PKN yang akan memberikan rekomendasi perangkat lunak untuk mengatasi masalah tersebut. Sustainability perangkat lunak didefinisikan sebagai perangkat lunak yang memiliki dampak negatif secara langsung maupun tidak langsung terhadap ekonomi, masyarakat, manusia dan lingkungan yang mengembangkan dan menggunakan suatu perangkat lunak. Sustainability performance metrics memiliki 10 parameter dalam pengukuran antara lain: modifiability dan reusability, portability, supportability, performance, dependability, usability, accessibility, predecability, efficiency dan project's footprint. Berdasarkan hasil analisa dapat 3 parameter dari 10 parameter sustainability performance metrics yang bermasalah yaitu modifiability dan reusability, accessability dan project footprint. Sehingga didapatkan nilai sustainability $70 \%$ yang dapat dikatakan tergolong bagus.
\end{abstract}

Kata Kunci: Sistem Informasi, SIM PKN, Sustainability, Sustainability Performance Metrics, 10 Parameter Metrics

\begin{abstract}
Information Management System Praktik Kerja Nyata (SIM PKN) is a service facility for University of muhammadiyah malang of department informatics engineering to students, academic lecturers and other academic circles by providing academic information systems that are in accordance with existing developments. The use of SIM PKN has the possibility to be used continuously. Without significant changes, this system will be difficult to meet the needs that are sustainable. Therefore it is necessary to measure sustainability using the sustainability performance metrics on SIM PKN which will provide software recommendations to overcome the problem. Software sustainability is defined as software that has a direct or indirect negative impact on the economy, society, people and the environment that develops and uses software. Sustainability performance metrics have 10 parameters in measurement including: modifiability and reusability, portability, supportability, performance, dependability, usability, accessibility, predecability, efficiency and project's footprint. Based on the analysis results, there is 3 parameters out of 10 parameters of sustainability performance metrics that have problems, its modifiability and reusability, accessability and project footprint. Based on result, the sustainability value is $70 \%$ which can be said to be quite good.
\end{abstract}

Keywords: Information System, SIM PKN, Sustainability, Sustainability Performance Metrics, 10 Parameter Metrics

\section{Pendahuluan}

Perangkat lunak memiliki dua kategori pengukuran yaitu pengukuran langsung dan pengukuran tidak langsung. Pengukuran langsung mencakup baris kode yang diproduksi, kecepatan eksekusi produk, kapasitas memori, dan cacat yang dilaporkan dalam waktu periode 
tertentu. Pengukuran perangkat lunak tidak langsung meliputi fungsionalitas, kompleksitas, efisiensi, keandalan, dan lain sebagainya. Karakteristik ini adalah karakteristik perangkat lunak tidak terukur yang diuraikan dalam beberapa sub karakteristik dan metric karakteristik kualitas. Karakteristik yang tidak dapat diukur adalah dasar untuk menghasilkan metric yang dapat diukur [1]. Model kualitas perangkat lunak adalah sekumpulan karakteristik yang berhubungan untuk menentukan persyaratan kualitas dan menilai kualitas suatu perangkat lunak [1]. Terdapat 7 model dalam pengukuran kualitas perangkat lunak yaitu McCall's quality model, Boehm's quality model, Dromey quality model, FURPS Quality Model, Systemic Quality model, ISO 25010:2011, UcSoftC Quality Model, dan PQF. Dalam pengukuran sustainability melibatkan ketujuh model pengukuran kualitas perangkat lunak yang mengarah ke "capacity to endure" yang secara umumnya adalah kapasitas suatu perangkat lunak untuk bertahan dan pembangunan sustainability untuk memenuhi kebutuhan pada saat ini tanpa mengurangi kemampuan generasi selanjutnya.

Sustainability perangkat lunak juga didefinisikan sebagai perangkat lunak yang memiliki dampak negatif secara langsung maupun tidak langsung terhadap ekonomi, masyarakat, manusia dan lingkungan yang mengembangkan dan menggunakan suatu perangkat lunak [2]. Perkembangan perangkat lunak juga dilakukan pada suatu organisasi atau lembaga pendidikan untuk menghasilkan perangkat lunak yang memiliki pelayanan berkualitas[3]. Perangkat lunak dalam bentuk Sistem Informasi dalam sebuah organisasi atau lembaga pendidikan memiliki peran penting dalam meningkatkan daya saing [4]. Salah satu lembaga pendidikan yang mengikuti perkembangan teknologi adalah Universitas Muhammadiyah Malang (UMM) ini memberikan fasilitas pelayanan kepada mahasiswa, dosen akademik dan kalangan akademik lainnya dengan menyediakan Sistem Informasi akademik yang sesuai dengan perkembangan yang ada. Salah satu bentuk pemanfaatan teknologi informasi tersebut adalah Sistem Informasi Management Praktik Kerja Nyata (SIM PKN). Penggunaan SIM PKN memiliki kemungkinan untuk digunakan secara berkelanjutan. Tanpa adanya perubahan yang signifikan , sistem ini akan sulit untuk memenuhi kebutuhan yang sifatnya berkelanjutan. Sebagai contoh perubahan pada SIM PKN salah satunya terkait dengan kapasitas penyimpanan data pada sistem yang perlu ditingkatkan seiring berjalannya waktu. Hal ini dilakukan karena terdapat kenaikan mahasiswa informatika yang menggunakan sistem setiap tahunnya. Setiap tahunya diperkirakan ada kurang lebih 300 mahasiswa informatika yang akan melaksanakan Praktik Kerja Nyata (PKN). Dalam pelaksanaannya mahasiswa diharuskan memberikan laporan harian maupun laporan akhir melalui sistem tersebut. Hal tersebut mengakibatkan pemenuhan kapasitas data dalam sistem setiap tahunnya. Tanpa adanya perubahan terhadap kapasitas data sistem akan menyebabkan data melebihi kapasitas data tersedia.

Oleh karena itu diperlukan pengukuran sustainability pada SIM PKN melakukan serangkaian pengukuran untuk memantau kinerja sustainability SIM PKN selama rilis produk perangkat lunak. Metode yang digunakan peneliti Sustainability Performance Metrics dengan 10 parameter dalam pengukuran antara lain : modifiability dan reusability, portability, supportability, performance, dependability, usability, accessibility, predecability, efficiency dan project's footprint[5]. Hasil pengukuran akan memberikan rekomendasi perangkat lunak untuk mengatasi masalah tersebut. Sehingga dengan adanya pengukuran sustainability akan membantu untuk pengembangan perangkat lunak ketahap berikutnya.

\section{Metode Penelitian}

Dalam bab ini menjelaskan terkait metode dalam proses pelaksanaan penelitian, mencakup penjelasan-penjelasan tentang identifikasi masalah, studi literature, pengumpulan data, analisa hasil, rancangan rekomendasi dan kesimpulan. Tujuan dari bab ini adalah untuk memberikan gambar tentang apa yang akan dilakukan peneliti yang dapat dilihat pada Gambar 1.

Pada Gambar 1 dibawah ini, merupakan bentuk alur penelitian yang akan dilakukan oleh peneliti yang dimulai dengan pengidentifikasian masalah, studi literature untuk menemukan materi penunjang penelitian, pengumpulan data berupa source code dan parameter pengukuran, analisi data dan rancangan rekomendasi serta kesimpulan.

REPOSITOR, Vol. 2, No. 7, Juli 2020: 843-854 


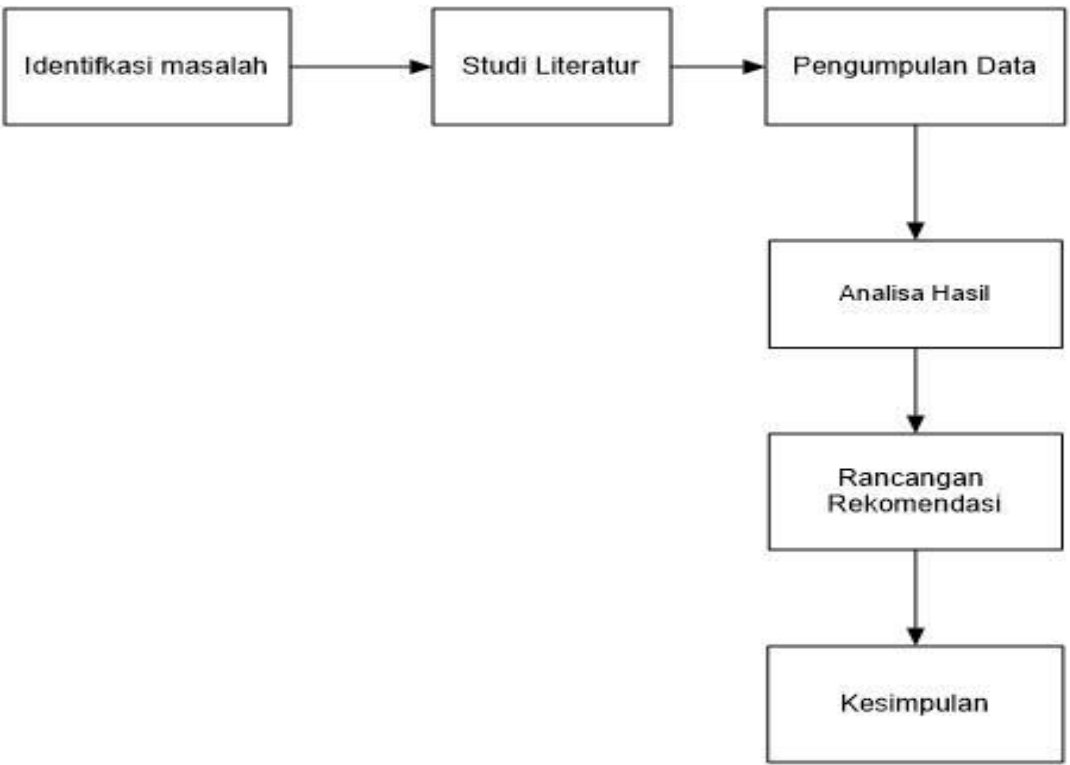

Gambar 1. Alur Penelitian

\subsection{Identifikasi Masalah}

Pada langkah ini yang paling utama harus dilakukan oleh peneliti setelah memperoleh dan menentukan topik penelitiannya adalah mengidentifikasi permasalahan yang hendak diteliti. Berdasarkan yang sudah dijelaskan diatas, maka peneliti mengidentifikasi permasalahan pada SIM PKN Teknik Informatika Universitas Muhammadiyah Malang bahwa sistem ini memiliki jangka waktu pengguna atau life time yang lama, sehingga diperlukan perubahan yang signifikan.

\subsection{Penentuan Kriteria}

Jika ada pertanyaan tentang apa yang akan teliti, maka jawabannya berkenaan dengan kriteria penelitian. Jadi kriteria penelitian pada dasarnya adalah segala sesuatu yang berbentuk apa saja yang ditetapkan oleh peneliti untuk dipelajari sehingga diperoleh informasi tentang hal tersebut, kemudian ditarik kesimpulannya. Ada beberapa kriteria yang digunakan untuk pengukuran sustainability diantaranya adalah :

1. Modifiability : Distance from main sequence

2. Reusability : Abstractness, Instability

3. Portability : Estimated System lifetime

4. Supportability : Support rate

5. Performance : Relative Response time

6. Dependability : Defect density, testing efficiency, testing effectiveness

7. Usability : Learnability, effectiveness, error rate

8. Accessibility : Support for motor- impaired users, visual impaired users, blind users, users with language and cognitive disabilities, illiterate users, dan internationalization, localization.

9. Predictability : Estimation quality rate

10. Efficiency : Project Efficiency

11.Project's Footprint: Work - from - home days, long- haul roundtrips

Dari kriteria diatas akan dianalisa dan diambil hasil beberapa kriteria yang sesuai dengan yang dibutuhkan sistem[5].

\subsection{Pengukuran Kriteria}

\section{a. Modifiability dan Reusability}

Modifiability adalah tingkat kemudahan sebuah sistem atau komponen agar dapat dimodifikasi untuk penggunaan dalam suatu aplikasi [6]. Sedangkan untuk Reusability adalah tingkat kemampuan perangkat lunak atau bagian perangkat lunak untuk dapat digunakan ulang di lain tempat sebagai komponen yang reusable [7]. Metric pertama yang akan dianalisis adalah Instability dengan Persamaan 1 sebagai berikut. 


$$
I=\mathrm{Ce} /(\mathrm{Ca}+\mathrm{Ce})
$$

Dimana :

Ce : Efferent Couplings (Ce): Jumlah kelas di dalam paket yang tergantung pada kelas di luar paket

$\mathrm{Ca}$ : Afferent Couplings (Ca): Jumlah kelas di luar paket yang tergantung pada kelas dalam paket

Matriks kedua akan dianalisis adalah Abstractness, dimana perlu diukur untuk mengetahui seberapa banyak package yang dapat menerima perubahan, dengan Persamaan 2 sebagai berikut.

$$
A=\mathrm{Na} / \mathrm{Nc}
$$

Dimana :

$\mathrm{Na}:$ Jumlah kelas abstrak dalam paket yang diberikan

Nc : Jumlah kelas konkret dalam paket yang diberikan

Abstractness memiliki ketentuan range berkisar dari 0 hingga 1 , dimana jika nilai abstractness mendekati 0 atau sama dengan 0 maka package benar benar konkret, namun jika nilai abstractness mendekati 1 atau sama dengan 1 berarti sepenuhnya abstrak [3]. Dari analisis metric Instability dan Abstractness akan mengetahui seberapa jauh package dari keseimbangan yang diidealkan atau jarak dari main sequence, dengan Persaman 3 sebagai berikut.

$$
\mathrm{D}=|\mathrm{A}+\mathrm{I}-1|
$$

Dimana $\mathrm{D}$ adalah Distance. Penentuan package yang perlu dilakukan redesign atau refactoring berdasarkan range distance pada perhitungan. Dimana jika mendekati 0 atau sama dengan 1 package sudah ideal, dan jika nilai mendekati 1 atau sama dengan 1 package diperlukan redesign atau refaktoring.

\section{b. Portability}

Portability adalah kemudahan dalam pengaksesan sistem khususnya terkait dengan faktor waktu dan lokasi pengaksesan, serta perangkat atau teknologi yang digunakan untuk mengakses [7]. Hasil analisis portability berupa life time sistem yangdapat ditentukan dengan mendefinsikan platform yang digunakan, mendefinisikan kebutuhan hardware sehingga diketahui life time sistem.

\section{c. Supportability}

Supportability adalah kebutuhan terkait dengan dukungan dalam penggunaan sistem atau perangkat lunak. Metric support rate dapat dihitung dari jumlah pertanyaan dan waktu session. Dimana dengan ketentuan semakin kecil nilai support rate maka semakin bagus supportability sistem begitu pula sebaliknya. Persamaan 4 yang digunakan adalah sebagai berikut.

$$
\text { Support rate }=\frac{\text { jumlah pertanyaan }}{\text { waktu session }}
$$

\section{d. Performance}

Performance merupakan tingkatan dimana perangkat lunak dapat memberikan kinerja terhadap fungsi atau aksi dalam sebuah sistem [8]. Pengukuran performance terhadap sistem dilihat dari relative respons time (RRT) metric, dengan Persamaan 5 sebagai berikut.

$$
R R T=\frac{\text { Jumlah task yang memiliki response time tidak wajar }}{\text { total task yang ada pada sistem }}
$$


RRT adalah jumlah waktu yanh dihitung dari akhir permintaan yang diberikan user kepada sistem. RRT dapat didefinisikan sebagai ukuran kecepatan operasi sistem. Dimana semakin kecil nilai RRT semakin bagus performance sistem.

\section{e. Dependability}

Dependability merupakan nilai keandalan suatu sistem untuk menciptakan sistem dengan keandalan yang baik dalam menjalankan tugas atau programnya. Dalam perhitungan dependability dapat menggunaka Persamaan 6, Persamaaan 7, dan Persamaan 8 sebagai berikut.

$$
\begin{gathered}
\text { Defect Density }= \\
\frac{\text { Kerusakan yang diketahui (ditemukan tetapi tidak dihap }}{\text { LOC (baris kode) }} \\
\text { Efisiensi Pengujian }=\frac{\text { cacat ditemukan }}{\text { Hari pengujian }} \\
\text { Keefektifam pengujian }=\frac{\text { cacat ditemukan dan dihapus }}{\text { cacat ditemukan }}
\end{gathered}
$$

Dengan ketentuan range 0 hingga 1 , dimana jika hasil nilai semakin kecil maka akan semakin bagus suatu sistem.

\section{f. Usability}

Usability adalah tingkat usaha yang dibutuhkan untuk mempelajari, mengoperasikan, dan menggunakannya untuk tujuan yang diinginkan [5]. Dalam menilai usability digunakan Persamaan 9, Persamaan 10, dan Persamaan 11 sebagai berikut.

$$
\begin{gathered}
\text { learnability }= \\
\text { Jumlah menit untuk menyelesaikan } \\
\text { tugas penting pertama tanpa bantuan } \\
\hline \text { Jumlah menit sistem digunakan oleh pengguna } \\
\text { Efektiftas }= \\
\frac{\text { Jumlah tugas yang diselesaikan tanpa bantuc }}{\text { total jumlah tugas }} \\
\text { Error rate }= \\
\frac{\text { Jumlah tugas yang diselesaikan } t}{\text { totapi menyimpang dari tindakan normal jumlah tugas }}
\end{gathered}
$$

\section{g. Accessibility}

Accessibility (kemudahan akses) adalah dimensi kualitas sistem informasi dimana informasi yang diperlukan dapat diakses dengan mudah dari sistem informasi [9]. Meninjau accessibility beradasarkan kebutuhan dengan ketentuan skor $0=$ Non Existent, $1=$ Not Adequate, $2=$ Acceptable, $3=$ Adequate.

\section{h. Predictability}

Predictability adalah nilai yang didapatkan dari analisa prediksi ketahanan suatu aplikasi atau sistem berdasarkan life time. Dalam predictability menggunakan dua ketentuan perhitungan berdasarkan metode yang digunakan dalam pengerjaan project yaitu Agile dan nonagile. Dalam 
penelitian ini, peneliti menggunakan metode non agile, dimana normalnya perhitungan dai total hari pengerjaan project dan total delay pengerjaan, dalam bentuk Persamaan 12 sebagai berikut.

$$
\text { Predectability }=\frac{\text { total hari delay }}{\text { total hari pengerjaan }} \times 100 \%
$$

\section{i. Efficiency}

Efficiency adalah kemampuan dari produk/perangkat lunak yang memungkinkan pengguna untuk mengeluarkan sumber daya dalam jumlah yang tepat dalam kaitannya dengan efektivitas yang dicapai dalam konteks penggunaan tertentu [10]. Pada perhitungan efficiency dibutuhkan dokumentasi terkait task yang dibentuk pada awal dimulainya project sampai dengan akhir pengembangan project. Task dikelompokkan menjadi dua jenis yaitu effort towards deliverables (coding, user manual, dll) dan project-related effort (pemeliharaan infrastruktur, manajemen proyek, dII) [2]. Untuk mengetahui nilai efficiency project menggunakan Persamaan 13.

$$
\text { Project efficiency }=
$$

\section{j. Project Footprint} resource.

Project footprint akan melakukan analisa berdasarkan riwayat pengerjaan project terkait

\subsection{Analisa Hasil}

Pada tahap ini menampilkan hasil dari perhitungan pada masing masing kriteria yang telah dilakukan. Di mana hasil tersebut akan dianalisa dan hasil analisa digunakan sebagai acuan untuk tahap rancangan rekomendasi sistem.

\subsection{Rancangan Rekomendasi}

Rancangan rekomendasi akan disusun berdasarkan analisa hasil dari perhitungan kriteria sustainability. Dimana dari analisa hasil tersebut diketahui kekurangan dari setiap kriteria yang dapat digunakan untuk memberikan rekomendasi pada pengembangan sistem berikutnya.

\section{Hasil Penelitian dan Pembahasan}

Hasil analis ini akan dilakukan serangkaian pembahasan pada setiap fungsi pengumpulan data yang akan diproses pada metode Sustainability Performance Matrix. Dimana matrix penilaian menyesuaikan dengan perancangan pengukuran kriteria.

\subsection{Pengukuran Kriteria}

\section{1. modifiability dan reusability}

Pada Tabel 1, bagian ini menunjukkan perhitungan evaluasi modifiability dan reusability yang diawali dengan perhitungan nilai Afferent Coupling atau Ca dan nilai Efferent Coupling atau $\mathrm{Ce}$ yang mana data tersebut diperoleh dengan menggunakan script python yang bertujuan mengidentifikasi keterkaitan antar class dalam source code Sistem Informasi Praktik Kerja Nyata (SIM PKN).

Tabel 1. Hasil Evaluasi Modifiabiliy dan Reusability

\begin{tabular}{cccccc}
\hline Package & Ca & Ce & I & A & D \\
\hline Backend & 9 & 12 & 0.571428571 & 0 & 0.42857 \\
be_admin & 14 & 0 & 0 & 0 & 1.00000 \\
model_admin & 5 & 1 & 0.166666667 & 0 & 0.83333 \\
be_arsip & 22 & 0 & 0 & 0 & 1.00000 \\
$\ldots \ldots$ & $\ldots \ldots$ & $\ldots \ldots$ & $\ldots \ldots$ & $\ldots \ldots$ & $\ldots \ldots$ \\
\hline
\end{tabular}

REPOSITOR, Vol. 2, No. 7, Juli 2020: 843-854 
Berdasarkan perhitungan yang telah dilakukan maka diperoleh kesimpulan bahwa terdapat 35 package dari 59 total package yang memerlukan perubahan dikarenakan nilai Distance (D) yang dihasilkan mendekati 1 dan sama dengan 1.

\section{Portability}

Pada Tabel 2, bagian ini menjelaskan hasil evaluasi dari kondisi portability yang menunjukan tingkat kemampuan beradaptasi sistem terhadap kebutuhan perangkat keras, dalam hal ini semakin mudah suatu sistem diimplementasikan pada perangkat keras dengan spesifikasi yang minim akan memberi banyak keuntungan, selain itu bermanfaat untuk mengetahui lifetime suatu sistem. Kebutuhan hardware dapat didefinisikan melalui software yang digunakan untuk menjalankan SIM PKN.

Tabel 2. Data Lifetime Portability

\begin{tabular}{cc}
\hline Software, Framework dan Plugins & Tahun Rilis \\
\hline 1. database MySql 5.5.24 & 2012 \\
2. Codeigniter Framework 2.2 & 2014 \\
3. Php 5.4.26 & 2014 \\
4. Bootstrap 3.11 & 2014 \\
5. Jquery 1.10.2 & 2013 \\
\hline
\end{tabular}

Menunjukan bahwa software, framework dan plugins yang digunakan memiliki tahun rilis paling baru ditahun 2014 sehingga hardware paling lama yang digunakan adalah pada tahun 2014. Sistem ini sudah berjalan sampai pada tahun 2019, sehingga life time dari sistem ini adalah 5 tahun. Dapat disimpulkan, SIM PKN yang memiliki life time 5 tahun dikatakan bisa diterima, sehingga tidak diperlukan untuk mengupgrade hardware.

\section{Supportability}

Pada Tabel 3, bagian ini menjelaskan proses evaluasi supportability dari kemampuan sistem dalam menangani suatu proses yang telah dilakukan oleh user dalam suatu task. Dalam pengambilan data ini dilakukan oleh 6 user yang menjalankan suatu task dan akan diukur respondnya menggunakan mode development pada browser.

Tabel 3. Data Supportability

\begin{tabular}{cccccc}
\hline No & User & Running task & Waktu & Jumlah pertanyaan & Support rate \\
\hline 1 & Admin 1 & 12 & 30 & 6 & 0.20 \\
2 & Admin 2 & 12 & 30 & 4 & 0.13 \\
3 & User 1 & 11 & 30 & 8 & 0.27 \\
4 & User 2 & 11 & 30 & 6 & 0.20 \\
5 & User 3 & 11 & 30 & 5 & 0.17 \\
6 & User 4 & 11 & 30 & 3 & 0.1 \\
\hline \multicolumn{7}{c}{ Rata-rata } \\
\hline
\end{tabular}

Menunjukkan hasil dari proses pengujian yang dilakukan oleh 6 user yang dilakukan secara hampir bersamaan, dalam hal ini user yang dimaksud adalah orang yang belum pernah menggunakan SIM PKN sebelumnya, sehingga selain dapat menilai kemampuan sistem dalam menangani suatu task dari user, dapat juga mengukur tingkat kemudahan serta seberapa informative panduan dan petunjuk yang dicantumkan dalam halaman SIM PKN tersebut. Pengujian supportability dilakukan dengan menentukan waktu session selama 30 menit per user. Sehingga dapat disimpulkan dari nilai rata-rata support rate yang cukup baik, dengan pertanyaan yang muncul meliputi pertanyaan mengenai teknis penggunaan program dan tidak ada pertanyaan yang mengindikasikan sistem memiliki error tertentu.

\section{Performance}

Evaluasi performance yang bersumber dari Sistem Informasi Praktek Kerja Nyata (SIM PKN). SIM PKN memiliki beberapa fitur yang dapat digunakan user maupun admin. Setiap fitur memiliki beberapa task didalamnya. Untuk menentukan performance diperlukan jumlah task yang ada pada sistem dan dilakukan pengujian pada masing masing task tersebut. Dimana hasi yang 
didapatkan dari Dari perhitungan keseluruhan nilai rata-rata $R R T$ sebesar 0.652 maka dapat disimpulkan bahwa sistem ini memilik nilai performance yang baik.

\section{Dependability}

Pada bagian ini menjelaskan proses evaluasi dependability dengan menganalisa error pada program dan membandingkan jumlah error tersebut dengan banyaknya Line of Code (loc) pada suatu class atau package.

Tabel 5.Proses Pengumpulan Nilai Error dan Perhitungan

\begin{tabular}{ccccc}
\hline File & LOC & Defect density & Efisiensi & Efektifitas \\
\hline Backend & 11 & 0 & 0 & 1 \\
be_admin & 133 & 0 & 0 & 1 \\
modeladmin & 83 & 0 & 0 & 1 \\
be_arsip & 304 & 0 & 0 & 1 \\
model_arsip & 321 & 0 & 0 & 1 \\
be_dosen & 138 & 0 & 0 & 1 \\
model_dosen & 111 & 0 & 0 & 1 \\
be_homepage & 18 & 0 & 0 & 1 \\
be_instansi & 194 & 0 & 0 & 1 \\
model_instansi & 122 & 0 & 0 & 1 \\
$\ldots$ & $\ldots$ & $\ldots$ & $\ldots$ & $\ldots$ \\
\hline
\end{tabular}

Hasil Tabel 5, yakni evaluasi defect density yang diperoleh dengan membandingan jumlah error dengan nilai Line of Code sehingga diketahui nilai dependability pada SIM PKN. Selain itu dilakukan juga pengujian dengan mencari error berdasarkan pengujian sistem . Kesimpulan yang diperoleh dari analisa ini adalah semua code berjalan dengan benar karena jika ada error maka tentunya ada salah satu fungsi dalam sistem ini tidak akan berjalan sebagaimana mestinya.

\section{Usability}

Evaluasi usability berupa task, waktu penyelesaian task, dan urutan percobaan pada setiap task. Suatu proses yang telah dikerjakan oleh user akan dicatat waktu penyelesaiannya guna mengetahui nilai learnability dan efektifitas.

Tabel 6. Contoh Hasil Proses Data Usability

\begin{tabular}{|c|c|c|c|c|c|}
\hline User & Task & $\begin{array}{l}\text { Tugas } \\
\text { Penting }\end{array}$ & $\begin{array}{c}\text { Selesai } \\
\text { dengan } \\
\text { bantuan }\end{array}$ & $\begin{array}{c}\text { Selesai } \\
\text { tanpa } \\
\text { bantuan }\end{array}$ & $\begin{array}{l}\text { Waktu } \\
\text { (menit) }\end{array}$ \\
\hline \multirow[t]{13}{*}{ Admin } & $\begin{array}{l}\text { Cek Rating tempat atau } \\
\text { instansi PKN }\end{array}$ & & & $\square$ & 1 \\
\hline & $\begin{array}{c}\text { Memasukkan nilai PKN ke } \\
\text { sistem UMM }\end{array}$ & & $\square$ & & 4 \\
\hline & Terima/Tolak PKN & $\square$ & & $\square$ & 1 \\
\hline & $\begin{array}{c}\text { Memantau aktivitas PKN } \\
\text { dari laporan harian }\end{array}$ & & & $\square$ & 2 \\
\hline & $\begin{array}{l}\text { Menentukan dosen } \\
\text { pembimbing PKN }\end{array}$ & & $\square$ & & 3 \\
\hline & Cek data mahasiswa PKN & & & $\square$ & 4 \\
\hline & $\begin{array}{c}\text { Memberi rating tempat } \\
\text { PKN }\end{array}$ & & & $\square$ & 2 \\
\hline & Cek waktu PKN & & & $\square$ & 2 \\
\hline & $\begin{array}{c}\text { Cek Rating tempat atau } \\
\text { instansi PKN }\end{array}$ & & & $\square$ & 1 \\
\hline & & & & total waktu & 20 \\
\hline & & & & Learnability & 0.05 \\
\hline & & & & Efektifitas & 0.77 \\
\hline & & & & error rate & 0 \\
\hline
\end{tabular}

REPOSITOR, Vol. 2, No. 7, Juli 2020: 843-854 
Pada Tabel 6 adalah hasil evaluasi pengukuran usability bagi admin Perhitungan evaluasi usability meliputi 3 perhitungan yaitu nilai learnability, nilai efektifitas dan nilai error rate. nilai learnability untuk 2 user bernilai kecil dengan nilai 0.05 untuk admin dan 0.025 untuk mahasiswa sehingga nilai learnability dinilai bagus. Sedangkan pada nilai efektifitas untuk 2 user bernilai besar dengan nilai 0.77 untuk admin dan 0.90 untuk mahasiswa. Dan nilai error rate pada sistem adalah 0 dimana semakin kecil nilai error rate akan semakin bagus penggunaan sistem.

\section{Accessibility}

Evaluasi accessability berupa penyediaan informasi atau kondisi didalam perangkat lunak dengan Spesifikasi Kebutuhan Perangkat Lunak (SKPL) .

Tabel 7.Tabel Tabel Contoh Hasil Status Accessabilty

\begin{tabular}{|c|c|c|c|c|c|c|}
\hline \multirow[b]{2}{*}{ User } & \multirow[b]{2}{*}{ Fitur/Task } & \multicolumn{5}{|c|}{ Akses Khusus } \\
\hline & & 1 & 2 & 3 & 4 & 5 \\
\hline \multirow[t]{9}{*}{ Admin } & Cek data mahasiswa PKN & 1 & 0 & 0 & 0 & \\
\hline & Cek Rating tempat PKN & 1 & 0 & 0 & 0 & 0 \\
\hline & Cek waktu PKN & 1 & 0 & 0 & 0 & 0 \\
\hline & Terima/Tolak PKN & 1 & 0 & 0 & 0 & 0 \\
\hline & Memantau aktivitas PKN dari laporan harian & 1 & 0 & 0 & 0 & 0 \\
\hline & Menentukan dosen pembimbing PKN & 1 & 0 & 0 & 0 & 0 \\
\hline & memberi nilai PKN & 1 & 0 & 0 & 0 & 0 \\
\hline & Memberi rating tempat $\mathrm{PKN}$ & 1 & 0 & 0 & 0 & 0 \\
\hline & Memasukkan nilai PKN ke sistem UMM & 1 & 0 & 0 & 0 & 0 \\
\hline
\end{tabular}

Pada Tabel 7 adalah proses yang dilakukan dalam evaluasi Accessability yang dilakukan dengan meninjau accessibility menggunakan skor kebutuhan yang didefinisikan sebelumnya yang dinilai dengan ketentuan merujuk pada Tabel 8.

Tabel 8. Penilaian Accessibility

\begin{tabular}{|c|c|c|c|}
\hline No. & Accessibility & Skor & Keterangan \\
\hline 1. & Non existent & 0 & Fitur atau dukungan tersebut tidak tersedia \\
\hline 2. & Non adequate & 1 & $\begin{array}{c}\text { Fitur atau dukungan tersebut tersedia namun tidak } \\
\text { maksimal }\end{array}$ \\
\hline 3. & Acceptable & 2 & $\begin{array}{c}\text { Fitur atau dukungan tersebut dapat diterima dan } \\
\text { digunakan }\end{array}$ \\
\hline 4. & Adequate & 3 & $\begin{array}{c}\text { Fitur atau dukungan tersebut tersedia dan dapat } \\
\text { digunakan secara maksimal }\end{array}$ \\
\hline
\end{tabular}

Nilai yang diberikan pada ketersediaan akses khusus bagi pengguna atau user dengan gangguan fungsi motorik dalam kolom 1 bernilai 1 dengan alasan pemberian nilai ini karena pengguna atau user yang memiliki gangguan motorik dapat menambahkan perangkat pendukung tertentu yang disambungkan ke personal computer mereka untuk membantu mengoperasikan SIM PKN. Untuk kolom 2, 3, 4 dan 5 nilainya adalah 0 karena dukungan untuk pengguna dengan keterbatasan-keterbatasan tersebut belum tersedia pada SIM PKN.

\section{Predictability}

Evaluasi predictability berupa lama pengerjaan SIM PKN yang diperoleh dari runtutan pembuatan modul dan waktu yang dibutuhkan. Pengerjaan SIM PKN yang dilakukan memiliki total hari pengerjaan selama 71 hari dengan 4 hari delay pengerjaan. Berdasarkan perhitungan dihasilkan nilai predictability sebesar $5,6 \%$.

\section{Efficiency}

Perhitungan efficiency dibutuhkan dokumentasi terkait task yang dibentuk pada awal dimulainya project sampai dengan akhir pengembangan project. Dokumentasi hasil dari project terdapat 76 total task effort yang dikelompokkan menjadi dua jenis yaitu effort towards deliverables (coding, user manual, dII) sejumlah 67 taks effort dan project-related effort 
(pemeliharaan infrastruktur, manajemen proyek, dII) sejumlah 9 taks effort. Sehingga dapat disimpulkan dalam SIM PKN memiliki nilai efficiency yang bagus yaitu $89 \%$.

\section{Project footprint}

Pada bagian ini menjelaskan evaluasi dari project footprint terkait resource. Berdasarkan list keseluruhan task dalam pengerjaan SIM PKN terdapat 2 task yang tidak efisien.

\subsection{Rancangan rekomendasi}

Menampilkan hasil dari perhitungan pada masing masing kriteria yang telah dilakukan. Dimana hasil tersebut akan dianalisa dan hasil analisa digunakan sebagai acuan untuk tahap rancangan rekomendasi sistem.

Tabel 9. Keterangan Rekomendasi

\begin{tabular}{|c|c|c|}
\hline No & Parameter & Rancangan Rekomendasi \\
\hline 1 & $\begin{array}{l}\text { Modifiability dan } \\
\quad \text { Reusability }\end{array}$ & $\begin{array}{l}\text { Diperlukan penyusunan package ulang dikarenakan lebih dari } \\
50 \% \text { package yang perlu diperbaharui berdasarkan nilai yang } \\
\text { diperoleh. }\end{array}$ \\
\hline 2 & Portability & Life time bisa diterima, sehingga tidak perlu upgrade \\
\hline 3 & Supportability & $\begin{array}{l}\text { Secara teknis SIM PKN tidak ada indikasi error sehingga tidak } \\
\text { diperlu dilakukan perubahan berdasar nilai supportability. }\end{array}$ \\
\hline 4 & Performance & $\begin{array}{l}\text { Berdasarkan nilai rata-rata RRT disimpulkan performance } \\
\text { bernilai bagus, sehingga tidak diperlukan perbaikan. }\end{array}$ \\
\hline 5 & Dependability & $\begin{array}{l}\text { Berdasarkan hasil, dependability SIM PKN tidak diperlukan } \\
\text { perubahan. }\end{array}$ \\
\hline 6 & Usability & $\begin{array}{l}\text { Berdasarkan hasil nilai learnability dan efektiftas SIM PKN } \\
\text { mudah digunakan, sehingga tidak diperlukan perbaikan. }\end{array}$ \\
\hline 7 & Accessibility & $\begin{array}{l}\text { SIM PKN perlu memaksimalkan fitur yang mana bisa digunakan } \\
\text { untuk user yang memiliki keterbatasan atau gangguan motoric, } \\
\text { selain itu juga bisa menambahkan multi bahasa pada sistem. }\end{array}$ \\
\hline 8 & Predictability & Berdasarkan nilai predictability SIM PKN tidak perlu perbaikan. \\
\hline 9 & Efficiency & $\begin{array}{l}\text { Berdasarkan perhitungan nilai efficiency SIM PKN bagus, } \\
\text { sehingga tidak diperlukan perbaikan. }\end{array}$ \\
\hline 10. & Proejct Footprint & Diperlukan penghapusan effort yang tidak efisien. \\
\hline
\end{tabular}

Berdasarkan Tabel 9 terdapat 3 parameter dari 10 metrics sustainability yang perlu dilakukan pembaharuan atau perbaikan sesuai dengan rancangan rekomendasi. Untuk pengembangan SIM PKN kedepannya terdapat 3 poin penting, diantaranya :

1. Diperlukan refactoring atau penyusunan ulang 35 package yang ditemukan bermasalah berdasarkan hasil analisis.

2. Perlu untuk memaksimalkan fitur sehingga dapat digunakan untuk user atau pengguna yang memiliki keterbatasan atau gangguan motoric dan menambahkan fitur multi bahasa pada SIM PKN.

3. Perlu adanya penyusunan effort yang lebih efisien untuk memaksimalkan waktu pengerjaan.

\section{Kesimpulan}

Setelah melalui perhitungan parameter, dengan metode sustainability performance metrics dapat disimpulkan nilai sustainability. Nilai sustainability dapat diambil dari jumlah parameter yang tidak memerlukan perbaharuan atau perbaikan dibagi dengan jumlah parameter metrics sustainability . berdasarkan ketentuan diatas dalam SIM PKN didapatkan nilai sustainability adalah $70 \%$. Sehingga dapat disimpulkan bahwa nilai sustainability SIM PKN tergolong bagus. Adapun saran dalam penelitian ini adalah diperlukan penelitian lanjutan untuk menyempurnakan nilai sustainability dengan melihat aspek yang berbeda yaitu kapasitas hardware (local, remote dan dalam koneksi jaringan), dan dalam pengukuran error dapat menggunakan metode lain seperti whitebox dan blackbox.

\section{Referensi}

[1] H.Z. Nur Zuria, Hamdan. Abdul Razak, Yahaya, Jamaiah and Aziz. Deraman, "User Centric 
Software Quality Model For Sustainability: A Review," Lecture Notes on Software Engineering, Vol. 4. No. 3, 2016.

[2] Durdik. Zoya, Klatt. Benjamin, "Sustainability Guidelines for Long - Living Software Systems, "IEEE, 2012.

[3] Axelsson. Jakob, Skoglund. Mats, "Quality Assurance in Software Ecosystemns: A Systematic Literature Mapping and Research Agenda, "Journal of System anda Software, Vol.114 . 2016.

[4] Bastian. Ade, "Analisis Strategi Bisnis dan Perancangan Strategis Sistem Informasi Pada Perguruan Tinggi Swasta (Studi Kasus: Universitas Majalengka)," Infotech Journal, Vol. 1. No. 1, 2015.

[5] Albertao. Felipe, dkk, "Measuring the Sustainability Performance of Software Projects," IEEE International Conference on E-Business Engineering, 2010.

[6] Letelay, Kornelis. Azhari SN, "Evaluasi kualitas Perangkat Lunak Dengan Metrics Berorientasi Objek," Seminar Nasional Informatika, 2012.

[7] Alfian, Irfan, "Analisis Kualitas Sistem Aplikasi M-Libararu Diperpustakaan Universitas Gajah Mada, "IR-Perpustakaan Universitas Airlangga, 2012.

[8] Asrul Sani. Nisfu, Widjonarko Roestam, dkk "Perancangan Model Sistem Informasi Evaluasi Dan Monitoring Pelaksanaan Tridharma Peguruan Tinggi," Seminar Nasional Sistem Informasi Indonesia, 2015. [5] irfan alfian

[9] Rahayu. Siti Kurnia, dkk, "Analisis Budaya Organisasi Pada Pengembangan Sistem Informasi Di UNIKOM, "Majalah IImiah UNIKOM, Vol.2 . No.12.

[10] Prastawa. Heru, dkk, "Pengembangan Model Pengukuran Usability Yang Mempertimbangkan Aspek Kognitif dan Afektik Dengan Moderasi Dimensi Kultural: Research Fremwork," Seminar Nasional Teknik Industri BKSTI, 2014. 
REPOSITOR, Vol. 2, No. 7, Juli 2020: 843-854 